\title{
EL ARTE DE LA REPRESENTACIÓN DEL ESPACIO. MAPAS Y PLANOS DE LA COLECCIÓN MEDINACELI
}

\author{
ANTONIO SÁNCHEZ GoNZÁLEZ (ED.)
}

\author{
Huelva, Universidad de Huelva, 2017, 480 páginas \\ ISBN: 978-84-17066-30-7
}

En un trabajo de equipo El Arte de la representación del espacio nos ofrece la colección de mapas y planos del Archivo Ducal de la Casa de Medinaceli, en sus sedes de Toledo y Sevilla. Una invocación que de por sí, y al margen del interés y valor de los contenidos, se presenta sugestiva y nos permite la entrada en un cuerpo y establecimiento complejo y de difícil proceso, acaso vedado, y en el que todos hubiéramos querido hurgar.

Como manifiesta el responsable de la edición en el introito, la obra presenta dos partes bien diferenciadas: una inicial de estudios parciales y monográficos y otra el catálogo pormenorizado de los mapas, planos y croquis considerados de mayor interés.

Un equipo, como decíamos antes, encabezado por el profesor de la Universidad de Huelva e investigador principal del proyecto Antonio Sánchez González, editor, autor del prólogo y del capítulo inicial, donde se analiza el origen, procedencias y generalidades de la colección y Archivo Ducal, y al que cumplimentan los profesores de la Universidad de Granada Mario Ruiz Morales, en un interesante análisis de la representación como instrumento de poder y gobierno; de la Universidad de Sevilla Teodoro Falcón Márquez, en el estudio de la arquitectura civil y casas-palacio, Fernando Cruz Isidoro, en cuanto a la arquitectura defensiva, castillos, fortalezas y baluartes, Andrés Luque Teruel, en la aplicación religiosa, monasterios, iglesias y colegios; y de la de Huelva, también, Juan Antonio Márquez Domínguez, quien revisará la cartografía del parcelario, rural y urbano, de la Casa Ducal y agregadas. Estudios independientes entre sí pero que nos sitúan, y abordan, temáticamente el corpus documental a examen.

Pero si esclarecedores son estos capítulos preparatorios, trascendental, a la vez que hermoso, se revela el catálogo y segunda parte. Amplio, diría voluminoso, si bien no todos los existentes "Son todos los que están", las series de planos, cartas, croquis, plantas y alzados, o meros dibujos hacen la mejor razón del título de la obra, El Arte de la representación del espacio, a la que al margen de las propias consideraciones plásticas y estéticas, tan destacables como curiosas, se añaden las históricas y didácticas, todas ellas, unas y otras, de peso. En este caso, al equipo citado hay que unir a Joaquín Cortés José, miembro del Instituto de Estadística y

\footnotetext{
${ }^{1}$ Antonio Sánchez González, Prólogo, p. 11.
} 
Cartografía de Andalucía. Una completa reseña de cada original, a cuya adscripción y transcripción acompaña la reproducción de la imagen y bibliografía, entre otras observaciones, nos abre la lectura y su mejor conocimiento. Igualmente, el seguimiento del orden alfabético de los lugares, provista la diversidad de los dominios y señoríos, da continuidad a la vez que compartimenta y precisa las series. Una agrupación tan lógica como efectiva.

En este sentido conviene destacar que si bien el tratamiento de los documentos mantiene una secuencia uniforme, llámese ficha -hay un apartado justificativo y aclaratorio de ello- la observación y deje individualizado de cada uno nos abre un sorprendente abanico de espacios y lugares, intenciones y procedimientos, modos y técnicas de representación, referencias internas y externas, y más cosas, particularmente, evocaciones e imaginarios, que nos permite el interés y acercamiento parcial del registro e, incluso, privativo de cada ficha y plano.

Un interés que se reparte por toda la geografía española, hay casos también del extranjero, desde Tarifa a Gerona, Guipúzcoa o La Coruña, pasando por las dos Castillas y el Levante y Extremadura. Y variedad temática, que anunciada en los estudios previos, nos conduce a todo tipo de obra, pública y civil, militar y religiosa, a la intemperie y de interiores, con especial atención a planos, plantas y alzados, y algún detalle, tratados todos con pulcra delicadeza, ajustadas líneas y afinada iluminación. Si por rédito personal he prestado especial atención al cuerpo gaditano no menos seducción me han procurado los destinados a los espacios abiertos, el litoral, con sus ondas y navíos, los montes, ríos y dehesas, de diferenciada vegetación, y los incorporados por la mano del hombre, amplios paseos y alamedas a la vez que recoletos rincones ajardinados. En todos, y cualquier caso, un tesoro gráfico e ilustrativo, histórico y didáctico, de incalculables dimensiones.

Y, acorde con el originario proyecto, I + D de Excelencia (HAR2013-41500-P) financiado por el Ministerio de Economía y Competitividad de España, con la extraordinaria identidad y grueso de la Colección y el esfuerzo de sus autores es la realidad de la presente edición. Un volumen de 480 páginas, con más de 650 imágenes a todo color, de las que cabe destacar el trabajo de digitalización y reproducción -más, aún, dadas las circunstancias y condiciones del material-, sólido, bien proporcionado y atractivo. Una tirada que el servicio de publicaciones de la Universidad de Huelva completa con los formatos PDF interactivo (eISBN 978-84-17066-31-4) y libro electrónico (epubISBN 978-84-17066-32-1).

Juan Ramón Cirici Narváez

Universidad de Cádiz 